\title{
College Students' Ideological and Political Education from the Perspective of Innovation and Development Concept
}

\author{
Jiang Wei \\ (Chengde Petroleum College, China Hebei067000)
}

Keywords: Innovative concept; Ideological and political education; Reform; Strategy

\begin{abstract}
The ideological and political education of college students has the characteristics of effectiveness, pertinence and time. In the new era, the traditional ideological and political education mode and thought can no longer meet the requirements of the development of education. In this paper, based on the concept of innovation, this paper briefly discusses the significance of college students' ideological and political education innovation, and puts forward innovative suggestions from the perspectives of educational content, educational concepts and educational carriers.

Innovation is the mainstream thinking of the current era development, especially pointing out the new development direction of the development of education. It is also an important way to promote the continuous improvement of traditional college students' ideological and political education and improve their effectiveness. The ideological and political education of college students should keep pace with the times, conform to the trend of education reform and development, actively innovate, take the initiative to meet the challenges brought about by ideological and political education in the new era and realize the sustainable development of ideological and political education to bring positive and beneficial effects to the overall development of college students.
\end{abstract}

Part one the significance of integrating innovation elements of college students' ideological and political education from the perspective of innovation

The intrinsic requirements for improving the pertinence and timeliness of college students' ideological and political education

The pertinence and timeliness of college students' ideological and political education are remarkable. In order to cater to the rapid development of the concept of innovation, as an ideological and political education worker, we must consciously and actively try to innovate and actively innovate in teaching methods. In practice teaching, it is not difficult to find that the lack of pertinence and timeliness of ideological and political education has become a major obstacle to the effective development of education. This requires actively updating the concept of education, respecting and embodying the subjective status of students, correctly understanding the requirements of educational reform for the all-round development of college students, emancipating the mind and breaking through the limitations of traditional teaching ideas.However, there are still some teachers in the ideological and political education of college students who have one-sided problems in teaching students and objects, and the dogmatic and formalized teaching process. This problem has become a major problem that restricts the smooth development of education reform. Under the concept of innovation and development, it is required that the ideological and political education of college students should face the society, cater to the times, respond to the society and intensify innovation in order to reflect the pertinence and timeliness of ideological and political education.

Playing a positive role in enhancing the appeal of college students' ideological and political education

The ideological and political education of college students aims to comprehensively improve the political and ideological quality of college students and develop a good ideological and moral quality. It is impossible to achieve this educational goal in one day. It is a long-term work. It requires constant exploration, experimentation and innovation to realize the sustainable development of college students' ideological and political education in order to effectively improve 
the level of education and open up new situations and ideas for ideological and political education. Under the guidance of the concept of innovation and development, the ideological and political education of college students needs to constantly update the teaching concept, enrich the teaching content, innovate the teaching mode and enhance the influence of the education work in order to effectively prevent the ideological and political education of college students from falling into a developmental dilemma and affecting the teaching effect and quality. At the same time, in the actual teaching, the ideological and political education of college students should be closely related to the actual life and close to the students which will be affecting the students in the subtle influence, internalizing the ideological and political theory and achieving the purpose of educating people. Therefore, in the ideological and political education of college students, the innovative concept is used as a guide to action, to link with the reality of life, to break through the rational and formalized problems of the traditional teaching model, so that students can accept it.

\section{Helping to promote the development of the ideological and political education of college students}

The ideological and political education of college students is constantly developing along with the development of society, so the education work should be consistent with the pace of social development. In the new era, it is inevitable that the ideological and political education of college students will be developed in the direction of internationalization and era in order to reflect the characteristics of the times and the function of educating people in ideological and political education. The reason why the ideological and political education of college students is constantly developing is that the ideological and political education cannot be separated from the historical foundation, nor can it isolate the world outside the real world, but it is consistent with the development of the times in order to achieve its goal of educating people and update the ideological concept of modern college students. Insisting on integrating the concept of innovation into the work of ideological and political education, and requiring that the educational work can rationally draw on and absorb other valuable elements, such as advanced and effective ideological and political education methods or other subject knowledge systems in other countries to improve ideological and political education. Efficiency plays a positive role. At the same time, scientific ideological and political education requires that college students can criticize and carry forward China's excellent traditions and valuable ideological and cultural resources with correct concepts and summarize and accumulate successful experiences. In addition, modern college students' ideological and political education work also requires continuous innovation of teaching content, mechanisms and functions to cater to the development of the times, and actively face the challenges brought by the development of the times.

\section{Part Two Suggestions on college students' ideological and political education based on the concept of innovation}

\section{Transforming the idea of college students' ideological and political education}

In recent years, innovation has become an important element of education reform and promotion. In order to cater to this development trend, it is necessary to infiltrate innovative elements in the ideological and political education of college students, try hard to try and explore and form educational concepts that are consistent with the development of the times. Firstly, under the concept of innovation, the work of ideological and political education should promote the all-round development of college students and the improvement of comprehensive quality as the fundamental of teaching. As the main body of ideological and political education, college students have vitality and their own unique thinking ability, and the purpose of ideological and political education which is to stimulate the creativity and subjectivity of college students and continuously cultivate the comprehensive quality of college students.Ideological and political education workers should correctly understand the characteristics of college students, change the concept of educational work, put students in the first place and promote the all-round development of college students as the starting point and ending point of education reflecting the main value of students; Secondly, under the guidance of innovative ideas, it should form a socialized educational work concept. The most 
prominent feature of ideological and political education is its social characteristics, which are influenced by external environment and historical conditions during the organization and implementation of educational work. Therefore, in the work of carrying out ideological and political education for college students, with the guidance of innovative ideas to encourage university students to pay attention to society, understand social development trends and hot issues and strive to integrate themselves into society which will be effectively solving the problem of the ideological and political education of college students from social reality. The work of ideological and political education should reflect the characteristics of birthing activation and strive to integrate elements of life.The ideological and political education of college students should come from life. Therefore, in the work of ideological and political education, both the content and the form of education should be related to the actual life of students, and regard life as the starting point of ideological and political education, which helps to avoid the existence of ideological and political education for college students.Moreover, in the modern educational concept, it is undoubtedly a more effective teaching method to vigorously advocate the teaching method of teaching and learning.

Innovating and expanding the content of ideological and political education for college students

The content of education is the basic element of the ideological and political education of college students. All educational activities are carried out around the content of education. Under the concept of innovation, we should actively innovate and expand the content of education, expand the scope of ideological and political education and realize its educational function, and effectively improve the comprehensive ability of students. In the development of modern society, the thoughts and behaviors of college students all show the imprint of the new era. Therefore, the ideological and political education of college students must correctly understand this characteristic of the times. In the education work, it should be changed from ideological concepts, systems, functions and content methods. It is an important reflection of the ideological and political education of college students and the development of the times. As an essential element of ideological and political education, we must advance with the times in the content of education and actively expand new areas. In the traditional ideological and political education work, teachers use theoretical indoctrination and moral preaching as the main teaching methods. The formal and rigid features are obvious. Without the interaction and interaction with students, they can not respond well to students' concerns and dispel students. By continuously innovating and adjusting the content of education, we can expand the knowledge of students and improve the pertinence, timeliness and quality of ideological and political education. When expanding educational content, educators should also understand social and educational issues in real time, make abstract theoretical knowledge more concrete, reflect their educational significance and stimulate students' enthusiasm for learning, compared with traditional boring teaching methods.

\section{Actively innovating the carrier of college students' ideological and political education}

Under the concept of innovation, carrying out ideological and political education for college students can improve the effectiveness of educational work with carriers or platforms that students are generally willing to accept. At present, in the process of ideological and political education, the main focus is on theoretical knowledge teaching and students' daily ideological and political education activities. The development of modern society is in the period of the agitation and confrontation of multicultural thoughts, which promotes the popularization of the network of ideological and political education. Under such circumstances, how to conduct scientific guidance and put forward new requirements and challenges for the theoretical teaching of ideological and political education. Based on the concept of innovation and the characteristics of the development of the times, the teaching of ideological and political theory should adhere to the guidance of socialist core values, pursue the patriotism ideal and innovative spirit, establish an active and healthy ideological culture and promote networking in ideological and political education. In the daily ideological and political education of students, educators should actively organize and encourage students to participate in campus cultural activities, regularly carry out social practice activities, carry forward the excellent traditional culture of our country, cultivate the excellent study 
style of college students and comprehensively improve the overall quality. The development of networking has pointed out the development direction for ideological and political education and provided a new way of thinking. Moreover, the popularity of the network has become a part of the life and study of college students. In the work of ideological and political education for college students, the network platform can be fully utilized and break the traditional classroom teaching model.

\section{Conclusion}

Through the above research, the author believes that in the new era, it is an inevitable trend to accelerate the innovation of ideological and political education among college students. It plays an important practical role in promoting the sustainable and healthy development of college students' ideological and political education and improving the comprehensive ability of college students. Based on this, under the guidance of the concept of innovation and development, educators must change their minds, explore new ideas for the development of ideological and political education, expand the content of education and the carrier of innovative education, make full use of the advantages of the Internet to promote the sound development of ideological and political education and realize its education.

\section{Reference}

[1]Mengqin Qiu. Research on the innovation of ideological and political education from the perspective of five developmental concepts[J]. Cultural and Educational Materials,2016(25):84-85.

[2] Yan Ma. Research on the innovation of college students' ideological and political education from the perspective of new media[J].Farm Staff,2017(12):254-255.

[3]Yonghua Chen. College students' ideological and political education from the perspective of innovation and development concept[J]. Continuing Education Research,2017(2):50-52. 